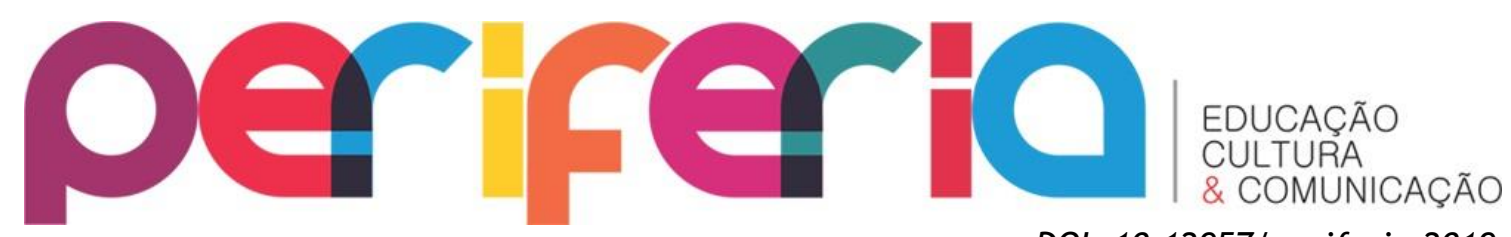

DOI: $10.12957 /$ periferia.2019.36382

\title{
A CAPOEIRA E A ESCOLA: UM OLHAR ETNOGRÁFICO
}

\author{
Vinícius Oliveira Pereira ${ }^{1}$ \\ Universidade do Estado do Rio de Janeiro - UERJ
}

\section{Resumo}

O artigo se propõe a discutir as implicações do diálogo entre uma escola da educação básica da rede municipal de ensino da cidade de Nova Iguaçu/RJ e a capoeira. Tratase de uma etnografia das aulas de capoeira que envolveu diferentes sujeitos do espaço escolar: oficineira de capoeira, professoras e estudantes. A escola analisada trabalhou com a capoeira a partir do Programa Mais Educação, que, entre outros objetivos, visa aumentar a permanência de estudantes no espaço escolar a partir da oferta de atividades educativas no contra turno escolar. As considerações finais apontam que a vinculação da capoeira com a cultura afro-brasileira, por vezes, tem sido rejeitada devido à presença de traços que a conectam com a religiosidade de matriz africana, sobretudo o candomblé e a umbanda. Diante desse contexto, identificamos, nas aulas de capoeira, tentativas de "esportizar" a manifestação como forma de lidar com a intolerância religiosa presente no cotidiano escolar.

Palavras chaves: capoeira; escola; cultura afro-brasileira

\footnotetext{
${ }^{1}$ Doutorando em Educação no Programa de Pós-Graduação em Educação da UERJ (ProPed - UERJ). Graduado em Pedagogia pela Universidade do Estado do Rio de Janeiro (2013) e Mestre em Educação, Cultura e Comunicação em Periferias Urbanas (2016). viniciusoliveirapereira@yahoo.com.br
} 


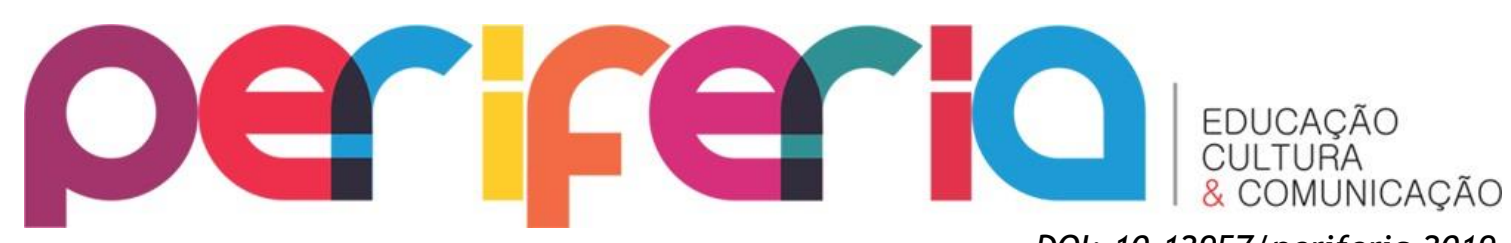

DOI: $10.12957 /$ periferia.2019.36382

\title{
CAPOEIRA AND ELEMENTARY SCHOOL: AN ETHNOGRAPHIC LOOK
}

\begin{abstract}
The article proposes to discuss the implications of the dialogue between a school of basic education of the municipal educaction network of the city of Nova Iguaçu / RJ and capoeira. It is an ethnography of capoeira classes that involved different subjects of the school space: capoeira officinaira, teachers and students. The analyzed school worked with the capoeira from the Programa Mais Educação, which, among other objectives, aims to increase the permanence of students in the school space from the offer of educational activities in the school shift. The final considerations point out that the link between capoeira and Afro-Brazilian culture has sometimes been rejected due to the presence of traits that connect it with the religiosity of the African matrix, especially candomblé and umbanda. Facing this context, we identified, in capoeira classes, attempts to "sport" manifestation as a way of dealing with religious intolerance present in school everyday.
\end{abstract}

Keywords: capoeira; school; afro-brazilian culture 


\section{periferio}

DOI: $10.12957 /$ periferia.2019.36382

\section{CAPOEIRA Y ESCUELA PRIMARIA: UNA MIRADA ETNOGRÁFICA}

\section{Resumen}

El artículo propone discutir las implicaciones del diálogo entre una escuela de educación básica de la red municipal de enseñanza de la ciudad de Nova Iguaçu / RJ y la capoeira. Es una etnografía de las clases de capoeira que involucró diferentes materias del espacio escolar: taller de capoeira, docentes y estudiantes. La escuela analizada trabajó con la capoeira del Programa Más Educación, que, entre otros objetivos, tiene como objetivo aumentar la tiempo de los estudiantes en el espacio escolar a partir de la oferta de actividades educativas en el turno escolar. Las consideraciones finales señalan que el vínculo entre la capoeira y la cultura afrobrasileña a veces ha sido rechazado debido a la presencia de rasgos que lo conectan con la religiosidad de la matriz africana, especialmente candomblé y umbanda. Frente a este contexto, identificamos, en clases de capoeira, intentos de manifestación "deportiva" como una forma de lidiar con la intolerancia religiosa presente en la escuela todos los días.

Palabras clave: capoeira; escuela; cultura afro-brasileña 


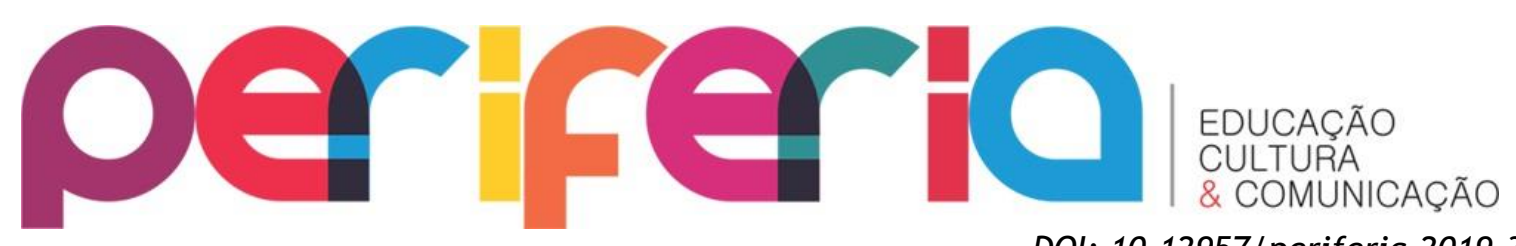

INTRODUÇÃO

DOI: $10.12957 /$ periferia.2019.36382

Ao pensar nos objetivos ${ }^{2}$ delineados no projeto de pesquisa de mestrado, a observação das aulas de capoeira em uma unidade escolar destacava-se como um caminho metodológico a ser necessariamente percorrido. Apesar da ansiedade para dar início ao trabalho de campo, os primeiros passos da pesquisa concentram-se na estruturação do aporte teórico, pois “[...] é preciso que, primeiramente, se indique que a observação não prescinde de pressupostos teóricos que balizem o processo investigativo e sejam o seu ponto de partida, o código de leitura da realidade estudada" (TURA, 2011, p. 185).

Tendo estruturado o aporte teórico, ou seja, construído o ponto de partida, pude finalmente dar início à procura pela escola. Devo destacar que não foi um percurso fácil. Encontrar uma escola que trabalhasse com a capoeira e que estivesse disposta a abrir suas portas para um olhar externo se constituiu em um trajeto marcado por imprevistos e algumas dificuldades ${ }^{3}$. Nesse processo, conversei com colegas capoeiristas que me indicaram algumas escolas. No entanto, a maioria estava localizada no município do Rio de Janeiro e a pesquisa tinha como foco outros espaços urbanos, mais especificamente na Baixada Fluminense ${ }^{4}$.

Tendo em vista a escolha por desenvolver a pesquisa na Região da Baixada Fluminense, recebi com entusiasmo a informação sobre a possibilidade de acompanhar as aulas de capoeira em uma escola ${ }^{5}$ localizada em Nova Iguaçu ${ }^{6}$, maior

2 Entre os objetivos do projeto de pesquisa destaca-se pensar e discutir as implicações do diálogo entre a capoeira e uma escola da educação básica.

3 A dificuldade de acesso as informações sobre as escolas que trabalham com a capoeira se caracterizou como um dos obstáculos para o desenvolvimento da pesquisa.

4 A Baixada Fluminense é uma área composta por 13 municípios que compõem a Região Metropolitana do estado do Rio de Janeiro.

${ }^{5}$ Após a identificação da escola que trabalha com a capoeira, entrei em contato com a Secretaria Municipal de Educação de Nova Iguaçu a fim de obter autorização para acompanhar as aulas de capoeira.

6 Fui informado por um professor da referida escola que o início do trabalho com a capoeira se daria no segundo semestre de 2014. 


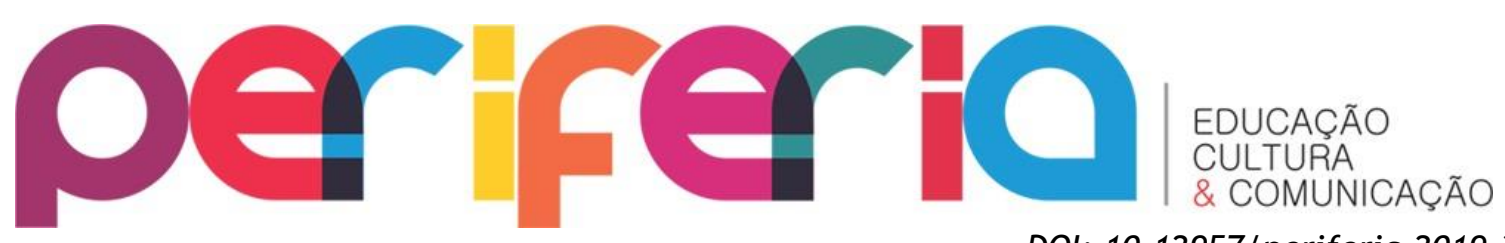

DOI: $10.12957 /$ periferia.2019.36382 município da Baixada Fluminense. De acordo com os dados ${ }^{7}$ do Instituto Brasileiro de Geografia e Estatística (IBGE), Nova Iguaçu apresenta uma extensão territorial de $519.159 \mathrm{~km}^{2}$. Em 2012, o número de habitantes era de 796.257 pessoas, sendo 414.507 mulheres e 381.750 homens. Ainda de acordo com informações do IBGE, a maioria da população de Nova Iguaçu é evangélica: 294.099 pessoas declararam ser evangélicas, 263.499 disseram ser católicas e 20.914 declararam-se espíritas.

Em termos educacionais, Nova Iguaçu possuía, em 2012, 49.093 pessoas matriculadas no ensino fundamental da rede municipal de ensino. Nesse mesmo ano, a rede era composta por 109 escolas municipais. Em 2013, a cidade teve a quarta pior média no Índice do Desenvolvimento da Educação Básica (IDEB) ${ }^{8}$ do $5^{\circ}$ ano do estado do Rio de Janeiro. De acordo com uma reportagem de um jornal fluminense publicada em 14 de setembro de 2014, enquanto a média nacional no IDEB de 2013 para o $5^{\circ}$ ano foi de 4,9, a média da cidade foi de 3,9. A baixa média no IDEB reflete, entre outras dificuldades, a precariedade da infraestrutura escolar:

Davi, de 6 anos, ainda está na fase de descobrir as letras, aprendendo a ler e escrever. No $1^{\circ}$ ano do ensino fundamental, o menino já conhece bem, no entanto, a dura realidade da educação pública em sua cidade. No início do mês, ele e seu pai, o pintor Michel Ramos Gomes, de 35 anos, encontraram o portão da Escola Municipal Marcílio Dias, em Nova Iguaçu, fechado. O problema se repetiu nos dias seguintes, sem explicação para as famílias dos cerca de 1.200 alunos. No quinto dia, Michel descobriu que as aulas estavam suspensas porque a bomba de água havia quebrado (ZUAZO, 2014).

A escola citada na reportagem apresentou, em 2013, uma das mais baixas médias no IDEB entre as unidades escolares municipais de Nova Iguaçu. É possível dizer que seu desempenho no IDEB é reflexo das dificuldades relatadas no trecho acima.

\footnotetext{
7 As informações foram retiradas do site do IBGE. Os dados são referentes ao ano de 2012. Para maiores informações: <http://cod.ibge.gov.br/2JQ>.

80 Índice de Desenvolvimento da Educação Básica (IDEB) foi criado pelo Instituto Nacional de Estudos e Pesquisas Educacionais Anísio Teixeira (INEP), em 2007. O IDEB reúne indicadores sobre o fluxo escolar e a média de desempenho nas avaliações. 0 fluxo escolar é obtido a partir dos dados sobre aprovação escolar presentes no Censo Escolar. A média de desempenho é obtida, nos municípios, a partir da Prova Brasil, exame aplicado as turmas do $5^{\circ}$ e do $9^{\circ}$ ano a cada dois anos.
} 


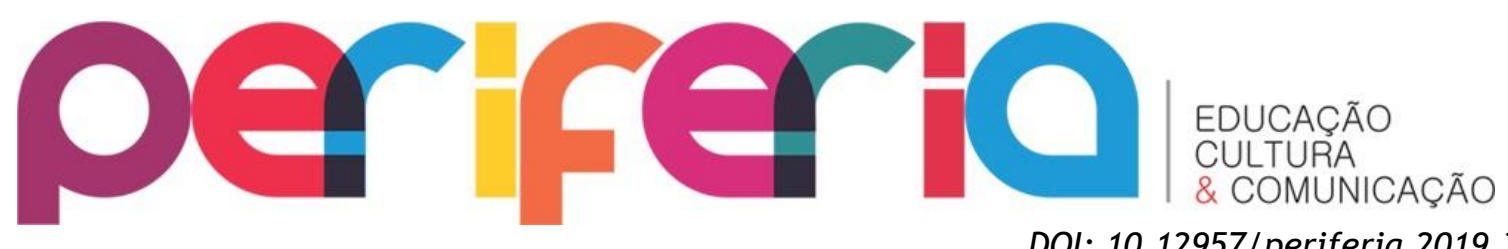

DOI: $10.12957 /$ periferia.2019.36382

Quando nos debruçamos sobre as condições das escolas públicas de Nova Iguaçu percebemos que as dificuldades em relação à infraestrutura são um problema que afeta a rotina de uma parcela considerável de escolas do referido município. Apesar de a escola onde realizei o acompanhamento das aulas de capoeira não sofrer com os mesmos problemas da Escola Municipal Marcilio Dias, ela também tem sua rotina afetada por questões que perpassam pela falta de espaço para o desenvolvimento das atividades educativas cotidianas. Mas esse ponto será abordado mais adiante; por enquanto, penso ser importante apresentar os primeiros contatos estabelecidos com a Escola Berimbau e com os sujeitos que a constituem.

\section{CONHECENDO A RODA: A ESCOLA BERIMBAU E SEUS SUJEITOS}

O primeiro contato com a escola ocorreu em uma tarde de agosto de 2014. Conheci a diretora e a coordenadora do Programa Mais Educação (PME) em meio ao fluxo de crianças, que aproveitavam as pequenas distrações dos adultos para correr pelo corredor principal. A minha chegada coincidiu com o horário de entrada e almoço das crianças. Dessa forma, precisei esperar algum tempo para poder conversar com a coordenadora do PME e explicar a proposta e os objetivos de minha pesquisa. Aproveitei o tempo de espera para observar a movimentação escolar. Durante o primeiro contato, pude notar a presença majoritária de estudantes negros, um número expressivo de mulheres entre o corpo docente e uma maioria feminina tímida entre o corpo discente, dada a diferença quase imperceptível entre os meninos e as meninas.

No decorrer da tarde, a movimentação no corredor foi diminuindo e pude finalmente conversar com a professora responsável por coordenar o PME. Ela trabalha na escola há cinco anos e tem o mesmo tempo de funcionalismo público na rede municipal de ensino de Nova Iguaçu ${ }^{10}$. Formada em Pedagogia, seu vínculo com a Prefeitura de Nova Iguaçu é como professora, mas há três anos ocupa a função de

\footnotetext{
${ }^{9}$ Durante o trabalho de campo, foi acordado com os sujeitos envolvidos na pesquisa que o anonimato seria mantido. 0 nome da escola também foi preservado. Nesse sentido, Escola Berimbau é um nome fictício.

10 Município da Região Metropolitana do Estado do Rio de Janeiro.
} 


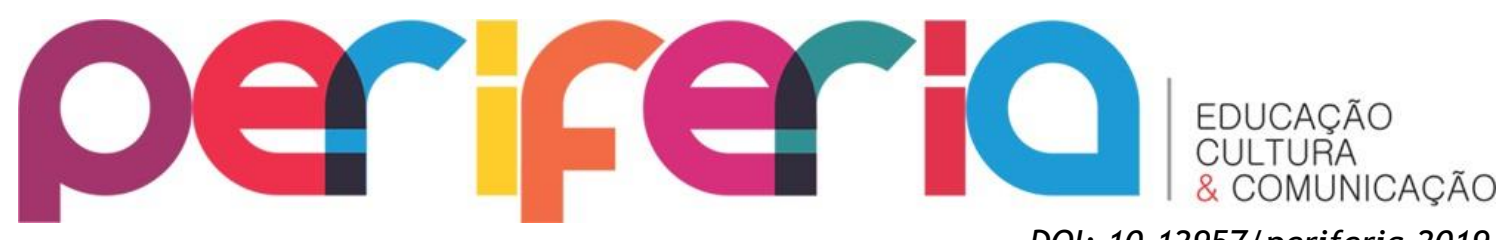

DOI: $10.12957 /$ periferia.2019.36382 coordenadora do PME, tendo sido indicada pela direção da unidade escolar. A indicação de uma pessoa do quadro de funcionários é uma das contrapartidas exigida pelo PME das secretarias de educação que se vinculam ao Programa:

Coordenador Interlocutor - Profissional com vínculo na secretaria, preferencialmente efetivo, com experiência em projetos educacionais, sociais e/ou culturais, com disponibilidade mínima de 20 horas por semana. Tem as responsabilidades de realizar a interface com a instância estadual (Comitê Metropolitano, se houver) e federal (SEB/MEC), fomentar e articular o Comitê Municipal, coordenar a implementação e execução da ação Relação Escola-Comunidade na secretaria e nas unidades da rede, elaborar e realizar ações de qualificação de atores e atividades das escolas, além de organizar e manter disponíveis os registros das ações (BRASIL, 2014, p. 34).

Em nosso diálogo inicial, apresentei a ela meu projeto de pesquisa e conversamos um pouco sobre a escola e as atividades desenvolvidas nesta pelo PME. Ela explicou que as aulas de capoeira haviam começado no segundo semestre de 2014, após o recesso de julho. A inclusão da capoeira nas atividades do PME se deu porque a escola foi procurada por uma capoeirista que vive no bairro onde a escola está localizada. Em entrevista realizada com a coordenadora do PME, a escolha da oficineira foi assim justificada:

A capoeira entrou porque chegou uma monitora de capoeira aqui na escola. Ela veio com o projeto e a gente abraçou. Como havia uma vaga no esporte, a gente encaixou ela. Porque no macrocampo Esporte havia essa possibilidade.

O movimento de aproximação entre a capoeirista e a Escola Berimbau se diferencia do que geralmente ocorre em outras unidades da rede de ensino de Nova Iguaçu. A coordenadora do PME na Secretaria Municipal de Educação de Nova Iguaçu (SEMED), ao falar sobre a escolha da pessoa que trabalha com capoeira, sinaliza:

Então como que a gente conhecia o monitor de capoeira? Uma vez que a gente não mora na comunidade. A gente falava com o pessoal do apoio, da cozinha: conhece alguém que trabalha com a capoeira? Aí o pessoal respondia: "ah, tem um rapaz que trabalha com capoeira ali na praça”, e então eu dizia: "traz o rapaz aqui”. 


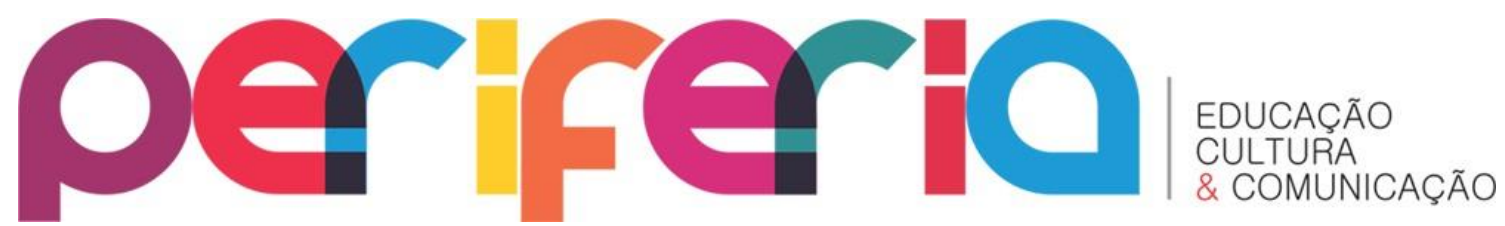

DOI: $10.12957 /$ periferia.2019.36382

O diálogo entre capoeiristas e escolas ocorre, de acordo com a coordenação do PME na SEMED, por iniciativa da escola que está interessada em trabalhar com a capoeira. No caso da Escola Berimbau, a procura se deu a partir da capoeirista, que foi até a instituição apresentar uma proposta de trabalho.

De acordo com a coordenadora do PME da Escola Berimbau, a introdução da capoeira foi possível porque havia uma vaga no esporte. Ela está se referindo ao macrocampo Esporte e Lazer, escolhido pela escola em 2014. No entanto, ao verificar a lista de atividades desse macrocampo, vemos:

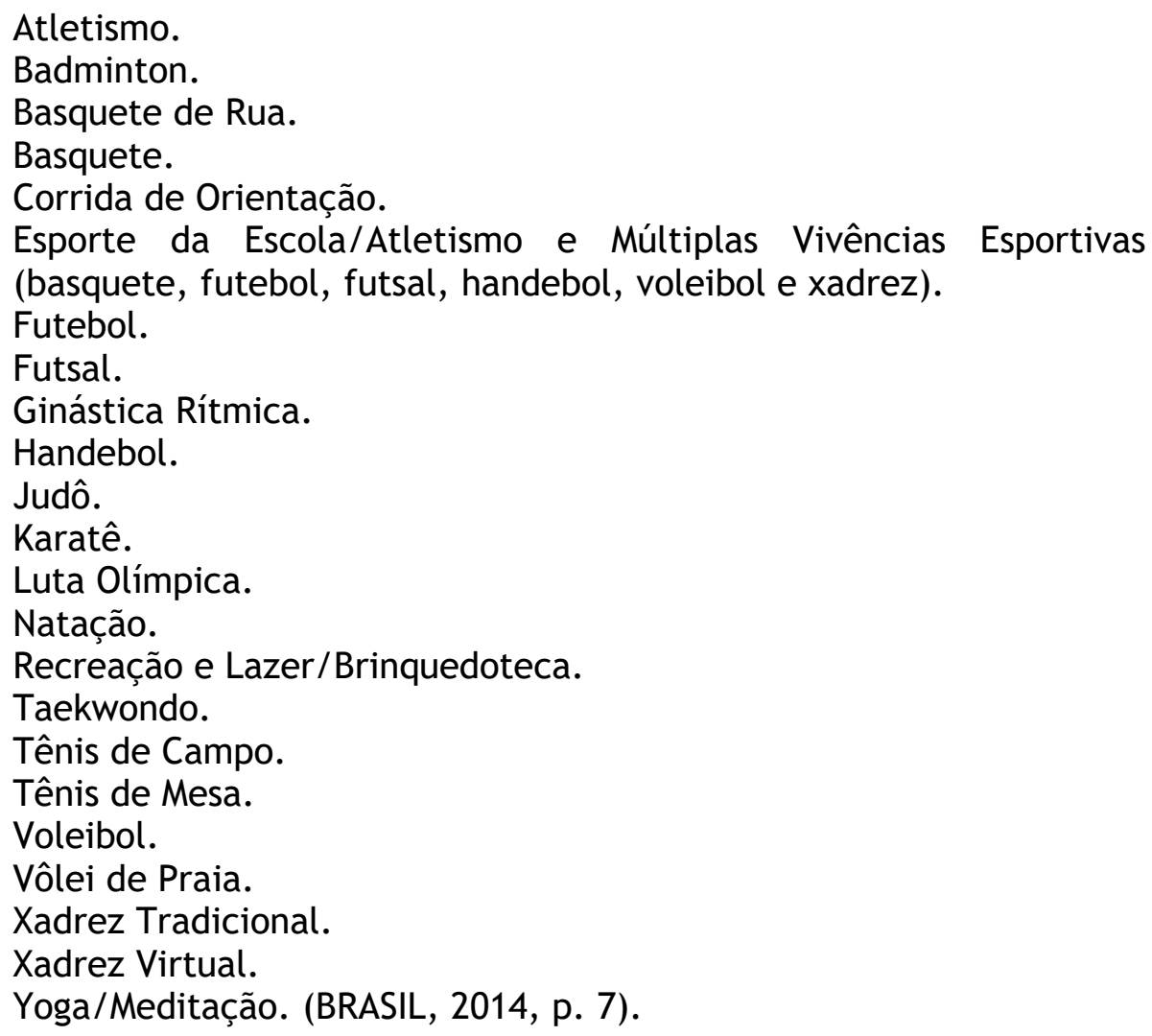

Como é possível verificar, a capoeira não está presente na lista de atividades que podem ser ofertadas pelas escolas que escolhem trabalhar com o macrocampo Esporte e Lazer. Essa situação parece dialogar com as considerações tecidas por Jefferson Mainardes (2006), que, baseado nas obras de Richard Bowe e Stephen 


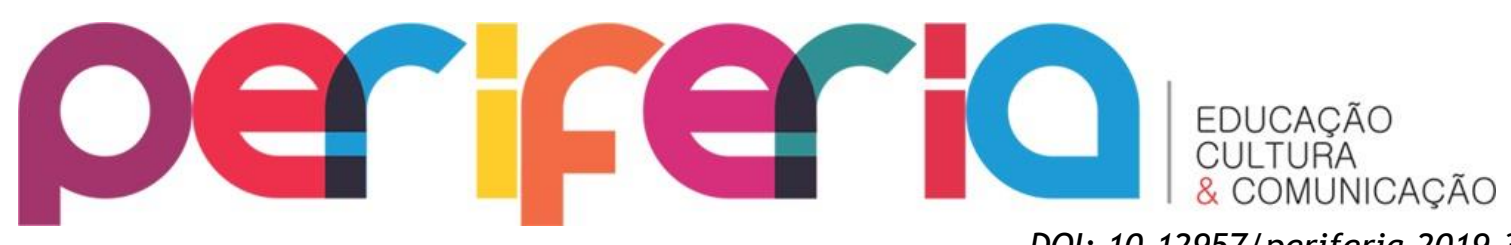

DOI: $10.12957 /$ periferia.2019.36382

Ball ${ }^{11}$, discute a relevância da abordagem do ciclo de políticas para pensar as políticas educacionais. 0 autor, ao apresentar o contexto da prática, pondera:

[...] o foco da análise de políticas deveria incidir sobre a formação do discurso da política e sobre a interpretação ativa que os profissionais que atuam no contexto da prática fazem para relacionar os textos da política à prática. Isso envolve identificar processos de resistência, acomodações, subterfúgios e conformismo dentro e entre as arenas da prática, e o delineamento de conflitos e disparidades entre os discursos nessas arenas (MAINARDES, 2006, p. 50).

Ao introduzir a capoeira como uma das atividades da escola, a coordenadora criou um subterfúgio em relação ao texto que regulamenta o PME, demonstrando a dinamicidade da implementação de uma política educacional. É possível que tal subterfúgio tenha sido criado por uma vontade da escola em oferecer a oficina de capoeira. Em nosso contato inicial, a coordenadora do PME da Berimbau sinalizou que o interesse da escola em oferecer a oficina de capoeira estava ligado à demanda dos estudantes, que já havia um tempo solicitavam a oferta da capoeira.

A Escola Berimbau atende 679 crianças, a maioria do sexo feminino. O corpo discente é constituído por 346 meninas e 333 meninos. O atendimento ao público é feito em dois turnos: o período da manhã funciona de $7 \mathrm{~h}$ às $11 \mathrm{~h}$ e o período da tarde funciona de $13 \mathrm{~h}$ às $17 \mathrm{~h}$. Apesar de não dispor de dados sobre o pertencimento étnico do corpo discente, tanto a direção da escola quanto o corpo docente são incisivos em apontar a predominância de crianças negras entre o corpo discente. As crianças dividem-se entre as turmas da educação infantil ao $5^{\circ}$ ano. Dessa forma, com exceção dos estudantes com defasagem idade-série, a faixa etária de atendimento da escola vai dos quatro aos onze anos de idade. A maioria das crianças atendidas moram no mesmo bairro onde a escola está localizada.

\footnotetext{
11 Para análise das políticas educacionais, Richard Bowe e Stephen Ball (1992) propõem um ciclo contínuo constituído por três contextos: o contexto de influência, o contexto da produção de texto e o contexto da prática. Como demonstra Mainardes (2006), esses contextos estão interrelacionados, não têm uma dimensão temporal ou sequencial e não são etapas lineares. Cada um desses contextos apresenta arenas, lugares e grupos de interesse e cada um deles envolve disputas e embates.
} 


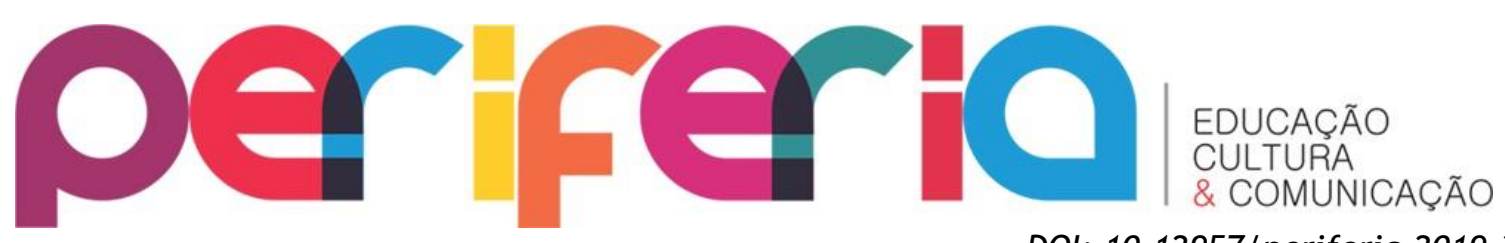

DOI: $10.12957 /$ periferia.2019.36382

O bairro da Escola Berimbau, denominado neste artigo como Meia Lua, está localizado próximo ao centro de Nova Iguaçu ${ }^{12}$. Apesar da proximidade da área central da cidade, o bairro caracteriza-se pela simplicidade, com casas e ruas modestas, onde há uma grande movimentação de bicicletas. Um passeio por suas ruas pode facilmente remeter o observador ao cenário de uma cidade pequena. No entanto, apesar da aparente tranquilidade, marcada pela utilização da bicicleta como meio de transporte, dos cavalos e vacas que pastam nos terrenos sem cerca, as narrativas da coordenadora apontam a presença do tráfico de drogas e a convivência com problemas de segurança pública.

Tendo em vista o cenário do bairro, a ampliação da jornada escolar de quatro para oito horas diárias é vista pelos familiares dos estudantes e pela coordenadora do PME da Escola Berimbau como uma das formas de garantir a segurança das crianças e de diminuir os riscos causados pela situação de vulnerabilidade social. Esse ponto parece ser uma questão recorrente no debate sobre a ampliação do tempo de permanência estudantil no espaço escolar:

Para enfrentar a situação de vulnerabilidade e risco social, a escola deve cumprir o duplo desafio de proteger e educar crianças, adolescentes e jovens por ela atendidos: [...] nesse duplo desafio educação/proteção - no contexto de uma "Educação integral em tempo integral", ampliam-se as possibilidades de atendimento (SILVA; SILVA, 2013, p. 703).

Nessa perspectiva, a escola é entendida como uma ferramenta para driblar os riscos sociais causados por situações de vulnerabilidade social. Sendo assim, a escola precisa equacionar a função de educar com a de proteger. No entanto, ALGEBAILE (2009), a partir de uma perspectiva crítica desse processo, nos alerta que a inclusão da função de proteção à infância e juventude nos objetivos da escola não pode ser utilizado como justificativa para diminuição de políticas sociais responsáveis justamente por tal função.

\footnotetext{
${ }^{12}$ A fim de preservar o anonimato dos sujeitos desta pesquisa, manterei o nome da escola e do bairro sob sigilo. Quando necessário, utilizarei nomes fictícios para designar o bairro, a escola e os sujeitos que constituem a comunidade escolar investigada.
} 


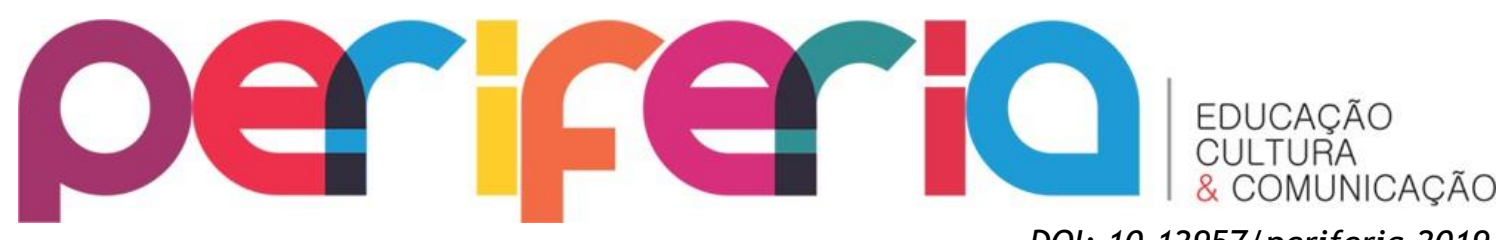

DOI: $10.12957 /$ periferia.2019.36382

A partir da implementação do PME, a Escola Berimbau passou a oferecer, no contraturno escolar, atividades como jornal escolar, percussão, orientação de estudos e leitura, esporte na escola (karatê, capoeira etc.) e tecnologias educacionais. Dessa forma, as crianças do ensino regular da manhã (7h às $11 \mathrm{~h}$ ), após o horário do almoço, ficavam até o turno da tarde. As crianças matriculadas no ensino regular da tarde chegavam à escola no período da manhã para participar das atividades. Em meu primeiro dia na escola, pude conhecer alguns oficineiros, responsáveis pelas oficinas supramencionadas. No entanto, não tive contato com a responsável pela oficina de capoeira, pois, devido a problemas pessoais, ela não pôde comparecer à escola naquele dia.

As oficinas do PME são destinadas às crianças do $1^{\circ}$ ao $5^{\circ}$ ano. No entanto, como sinaliza o MEC, o perfil do público deve atender preferencialmente aos seguintes pontos:

\footnotetext{
Recomenda-se às escolas que estabeleçam critérios claros e transparentes para a gradativa implementação da ampliação da jornada escolar na perspectiva da educação integral, selecionando, preferencialmente, para a participação no programa:

Estudantes que apresentam defasagem idade/ano;

Estudantes das séries finais da $1^{\text {a }}$ fase do ensino fundamental $\left(4^{\circ} \mathrm{e} / \mathrm{ou}\right.$ $5^{\circ}$ anos), onde existe maior saída espontânea de estudantes na transição para a $2^{\text {a }}$ fase;

Estudantes das séries finais da $2^{\mathrm{a}}$ fase do ensino fundamental $\left(8^{\circ} \mathrm{e} / \mathrm{ou}\right.$ $9^{\circ}$ anos), onde existe um alto índice de abandono após a conclusão; Estudantes de anos/séries onde são detectados índices de evasão e/ou repetência;

Estudantes beneficiários do Programa Bolsa Família. (BRASIL, 2014, p. 18).
}

Na Escola Berimbau o atendimento do PME é estendido a praticamente todas as turmas, com exceção da educação infantil. De acordo com a coordenadora, o critério utilizado é a autorização dos familiares, que permitem ou não que seus filhos e filhas participem das atividades oferecidas no contraturno escolar. Segundo a equipe escolar, o número de crianças atendidas já chegou a 200, o que representa quase um terço do corpo discente. 


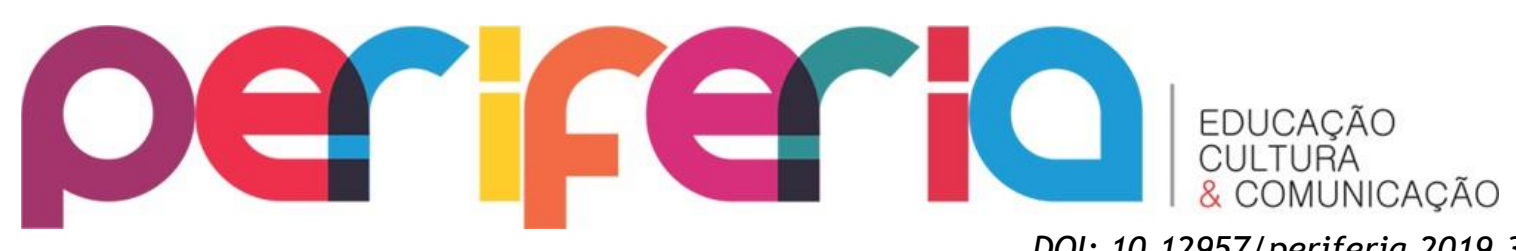

AS AULAS DE CAPOEIRA: TECENDO RETRATOS DA RODA

DOI: $10.12957 /$ periferia.2019.36382

Após obter a autorização da Secretaria Municipal de Educação de Nova Iguaçu, da direção escolar e da coordenação do PME da Escola Berimbau, faltava apenas a autorização da capoeirista responsável pela oficina de capoeira para dar início ao acompanhamento das aulas. Assim como fiz em minha primeira visita à escola, levei uma cópia do projeto de pesquisa para entregá-la. Em nosso primeiro contato, trocamos informações, expliquei os objetivos da pesquisa e explicitei o desejo de acompanhar suas aulas. Nesse momento, também pude obter algumas informações como, por exemplo, o grupo de capoeira ao qual ela está vinculada.

Sol ${ }^{13}$, como é conhecida entre seus alunos e colegas capoeiristas, está vinculada ao grupo Capoeira Brasil, um dos maiores grupos de capoeira contemporânea do Brasil. De acordo com informações obtidas no site de um dos mestres do grupo:

No dia 14 de janeiro de 1989, foi fundado na cidade de Niterói, no Rio de Janeiro, o Grupo Capoeira Brasil. Formado pelos Mestres Boneco, Paulão e Paulinho Sabiá [...], o grupo foi criado com o objetivo principal de manter viva toda a expressão da capoeira como arte, cultura e esporte. Desde sua criação, o grupo tem crescido e desenvolvido projetos em academias, escolas e ONGs em diversos países [...]. O grupo Capoeira Brasil desenvolve um estilo que tem como base a Capoeira Regional de Mestre Bimba, usando todos os elementos desenvolvidos por ele e mais a evolução dos movimentos da capoeira ao longo dos anos. Chamamos este estilo de Capoeira Regional Contemporânea. ${ }^{14}$

Como descrito nas informações sobre o grupo, seus integrantes têm se concentrado no desenvolvimento de projetos em diferentes espaços, com destaque para o campo escolar. Sol não foge à regra. Apesar de ser formada em administração, ela vive do trabalho com a capoeira: "Atualmente vivo a capoeira e da capoeira. Me

\footnotetext{
${ }^{13}$ A utilização de apelidos era uma estratégia dos capoeiristas para lidar com a perseguição policial durante o período em que a capoeira foi considerada ilegal. A utilização de apelidos é ainda hoje uma prática comum. Atualmente o batizado é um momento em que o capoeirista recebe ou oficializa seu apelido. Diferente de outros atores da pesquisa, a professora de capoeira não solicitou anonimato.

14 Disponível em: <http://www.kimcapoeira.com/gcb/grupo-capoeira-brasil/>. Acesso em: 10 jul. 2015.
} 


\section{periferio}

DOI: $10.12957 /$ periferia.2019.36382 formei em administração de empresas, mas há quatro anos abandonei os escritórios e trabalho só com a capoeira. Hoje eu atendo nove escolas”. Além de trabalhar na Berimbau, Sol desenvolve projetos em outras escolas de Nova Iguaçu, inclusive em unidades da rede privada de ensino.

Contudo, apesar de ter optado por viver da capoeira, Sol destaca em suas narrativas uma série de dificuldades encontradas por quem escolheu a capoeira como uma forma de conseguir o sustento:

As dificuldades que nós encontramos para desenvolver o trabalho com a capoeira nas escolas é a discriminação racial e religiosa. É a principal dificuldade que a gente encontra. [...] na instituição pública outros problemas são a falta de recursos, pois a escola não destina verba para atividade, espaço, que na maioria das vezes não tem um espaço adequado para atividade - o pátio em geral não é adequado para a prática da atividade - e material, pois, quando a escola coloca a atividade, não tem material para trabalhar. Então o profissional tem que levar o material de casa, o que acaba dificultando a aprendizagem da criançada em relação à musicalidade e outras coisas...

A narrativa da Sol apresenta uma série de dificuldades vividas por quem trabalha com capoeira e mais especificamente por quem trabalha com capoeira no PME. No caso da Escola Berimbau, apesar de ter conseguido ofertar a capoeira como uma de suas atividades sem ter escolhido o macrocampo Cultura, Artes e Educação Patrimonial, ao qual a oficina está vinculada, a escola sofreu alguns problemas decorrentes do subterfúgio criado para conseguir oferecer a oficina de capoeira. De imediato, destaca-se a impossibilidade de solicitar os materiais vinculados à oficina:

Calça de capoeira branca

Camisetas de malha fio 30

Agogô

Berimbau completo

Caxixi (instrumento musical)

Pandeiro (BRASIL, 2014, p. 63)

Como para a SEMED de Nova Iguaçu e para o PME, a escola não escolheu o macrocampo Cultura, Artes e Educação Patrimonial, área em que a capoeira está inserida, não foi possível solicitar os materiais descritos acima. 


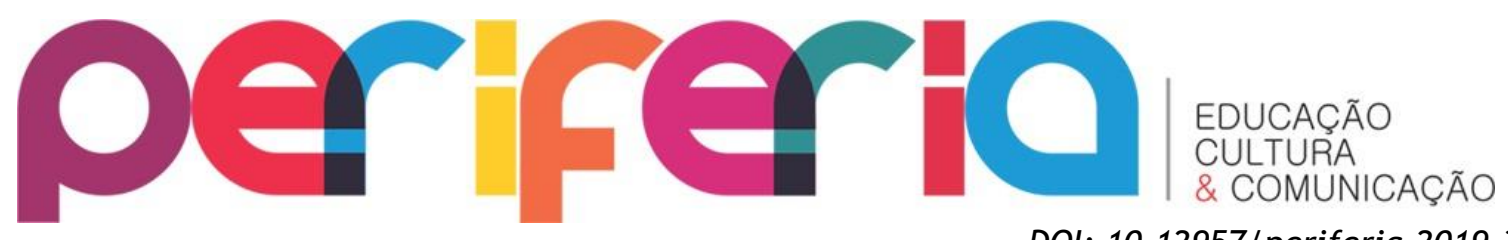

DOI: $10.12957 /$ periferia.2019.36382

Dessa forma, para desenvolver as atividades com a capoeira na Escola Berimbau, a capoeirista precisava trazer os instrumentos de casa. Essa situação interferia diretamente no desenvolvimento das aulas ${ }^{15}$, pois, durante 0 acompanhamento, ficou nítido para mim o interesse das crianças na musicalidade da capoeira. Quando a atividade exigia das crianças o manuseio de instrumentos musicais, o sucesso da aula era garantido:

\footnotetext{
${ }^{16}$ Pedro: Eu adoro tocar pandeiro.

Eu: Onde você aprendeu a tocar tão bem?

Pedro: Eu sempre toco lá na igreja.
}

Alguns alunos demonstravam uma habilidade incrível com os instrumentos, sobretudo com o pandeiro. A familiaridade de parte da turma com o instrumento deve-se ao fato de alguns estudantes terem contato com o instrumento na igreja. A abordagem musical nas aulas de capoeira chamou a atenção, também, pela possibilidade de inclusão de alunos com necessidades especiais. Um dos alunos era deficiente visual e sua habilidade em tocar o pandeiro chamava a atenção das demais crianças.

Apesar de a abordagem musical da capoeira ter boa receptividade entre as crianças, por conta da dificuldade da Sol em se deslocar com alguns instrumentos, o contato dos estudantes limitava-se aos instrumentos de menor tamanho como, por exemplo, pandeiro e caxixi. Infelizmente, durante o tempo em que acompanhei as aulas, não presenciei o encontro das crianças com o berimbau, instrumento que marca a identidade da capoeira e objeto de interesse de todas as crianças que participavam da oficina.

Ao me debruçar novamente sobre o relato da capoeirista acerca das dificuldades encontradas para a prática da capoeira, identifico na Escola Berimbau outros problemas apontados por ela. De fato, há uma série de problemas

\footnotetext{
${ }^{15} \mathrm{O}$ acompanhamento das aulas de capoeira ocorreu durante o período de 6 meses. As entrevistas com as professores regulares da escola, com a direção e com a professora de capoeira ocorreram durante esse tempo. Todas as entrevistas foram realizadas no espaço escolar, com exceção das entrevistas com as coordenadoras da Secretaria Municipal de Educação, que ocorreram na SME.

${ }^{16}$ Nome fictício.
} 


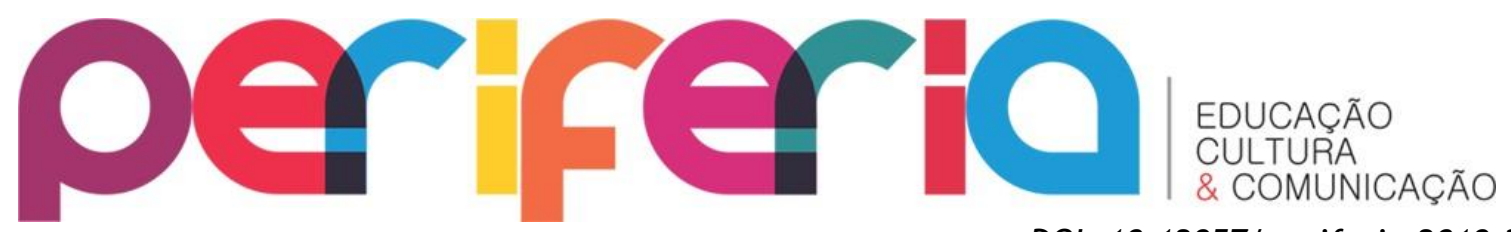

DOI: $10.12957 /$ periferia.2019.36382 infraestruturais que marcam a realidade das escolas públicas não apenas no município de Nova Iguaçu, mas no Brasil de um modo geral:

A falta de infraestrutura nas escolas públicas foi o problema mais citado por secretários municipais de Educação em levantamento realizado pelo Instituto Nacional de Estudos e Pesquisas Educacionais (Inep). De 3.410 secretários entrevistados - 61\% do total no país -, $24,1 \%$ apontaram as insuficiências de infraestrutura, juntamente com dificuldades de conservação dos prédios, como principais problemas da respectiva rede municipal. Em segundo lugar, a não participação das famílias e da comunidade $(16,2 \%)$, seguida pela dificuldade de inclusão de alunos com necessidades especiais $(13,1 \%)$ (WEBER, 2013).

As dificuldades da Escola Berimbau em relação à infraestrutura podem ser mais bem compreendidas a partir da imagem a seguir. Trata-se da planta do prédio onde a escola está sediada. A estrutura é composta por dez salas de aula, uma sala destinada à direção, uma sala dos professores, um laboratório de informática, uma sala de leitura (onde a equipe do PME trabalha), dois banheiros e um refeitório. $\mathrm{Na}$ área externa do prédio encontra-se uma quadra de esporte, local compartilhado pelo professor de educação física e pelos oficineiros de práticas esportivas e de capoeira.

Figura 1: Planta da Escola Berimbau

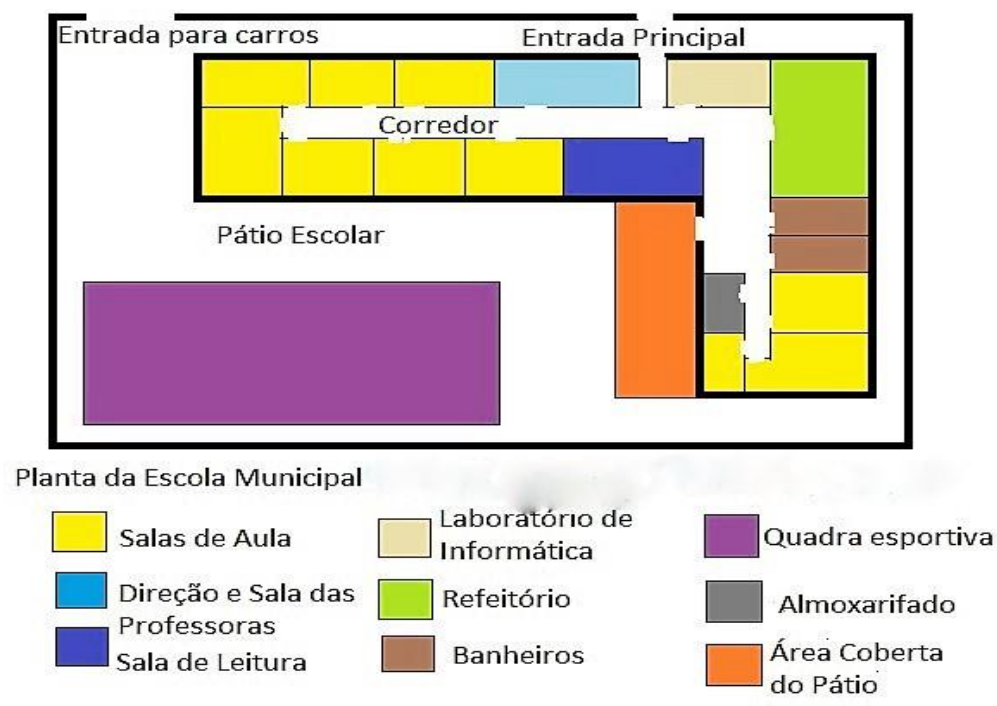

Fonte: 0 autor, 2016. 


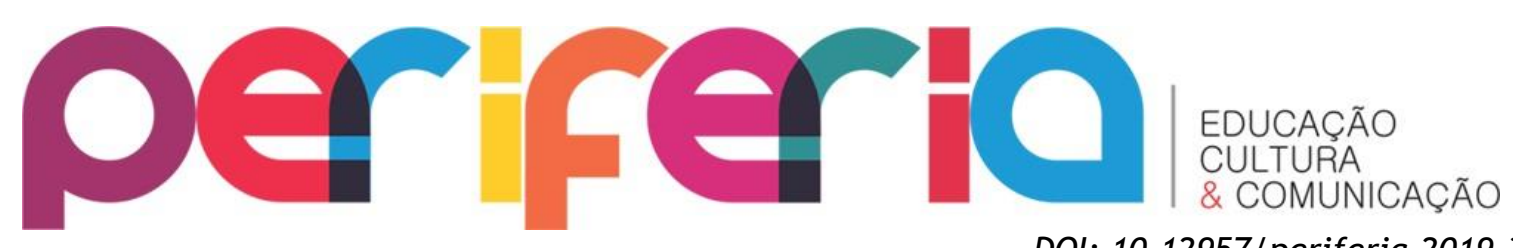

DOI: $10.12957 /$ periferia.2019.36382

A quadra e o pátio externo da escola não possuem cobertura, então os encontros de capoeira estão sujeitos às condições climáticas. Em dias de chuva, as aulas eram suspensas e, em dias de forte calor, a roda de capoeira era desfeita, pois as crianças e a oficineira buscavam proteger-se dos raios solares nas poucas sombras formadas pelas paredes das salas de aula. Dessa forma, se, por um lado, há um entendimento de que a oficina de capoeira consegue dialogar bem com a falta de estrutura das escolas ${ }^{17}$, o que a torna uma alternativa para lidar com tal problema, por outro, a observação das aulas demonstrou que, na prática, a oficina de capoeira também sofre com os problemas de infraestrutura apontados por secretários de educação como uma das maiores dificuldades das redes municipais de ensino do país.

Um aspecto que se destacou no relato da capoeirista responsável pela oficina de capoeira é o reconhecimento da intolerância religiosa como a maior dificuldade para o trabalho com a capoeira no espaço escolar. Esse ponto também esteve presente na conversa que tive com a coordenadora do PME na SEMED:

A única coisa que eu acho que sempre, desde sempre, desde que eu estive na escola, a capoeira tem como entrave é a questão religiosa. A comunidade liga à religião e pronto. A criança acaba não podendo fazer, porque eles acham que é uma religião afro, que a capoeira tem a ver com isso. Hoje eu estou um pouco distante, mas na época em que a gente ficava dentro das escolas, era muito forte. Muitas crianças podiam fazer tudo, mas não podiam fazer capoeira. Isso porque os pais eram evangélicos.

A narrativa da coordenadora demonstra que a dificuldade relatada pela capoeirista que trabalha na Escola Berimbau não é um fato isolado. Nesse sentido, é possível dizer que a intolerância religiosa se destaca como um elemento importante quando pensamos no diálogo da capoeira com a escola. Como sinaliza a coordenadora do PME, muitas famílias não permitem que seus filhos participem da oficina por entenderem que a capoeira possui uma ligação com religiões de matriz africana, como candomblé e umbanda.

17 Como afirmou a coordenadora do PME na SEMED de Nova Iguaçu durante a entrevista, "a capoeira você consegue fazer em qualquer cantinho". 


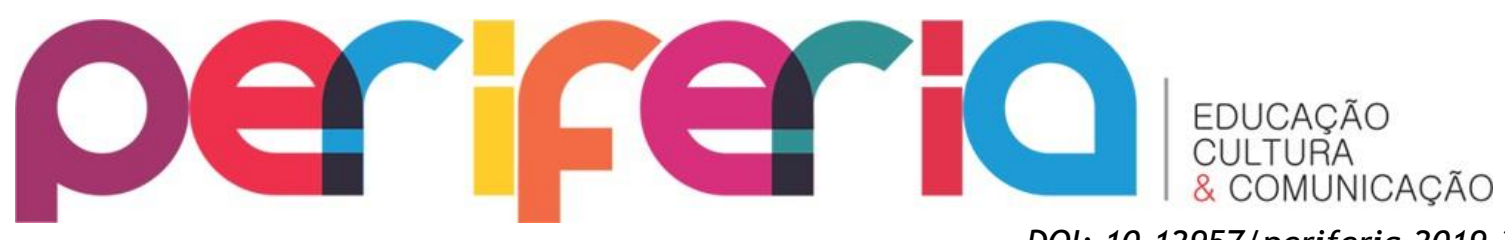

DOI: $10.12957 /$ periferia.2019.36382

$\mathrm{Na}$ tentativa de compreender esse fenômeno, dialogo com o trabalho de Rita Amaral e Vagner Gonçalves da Silva:

Candomblé e capoeira tiveram uma origem comum no período da escravidão e até hoje se pode identificar em ambos elementos comuns que os aproximam. A capoeira é uma luta, também considerada um jogo, que embora não tenha um caráter propriamente religioso apresenta referências ao candomblé e à umbanda. Evidentemente, para ser um capoeirista não é necessário ser "do santo", embora muitos o sejam e a capoeira, como sistema, compartilhe traços estruturais que revelam sua ligação com essas religiões. A mais evidente é a referência explícita aos orixás (seus nomes, cores e atributos) nas cantigas e nos nomes de alguns capoeiristas, como, por exemplo, Camafeu de Oxossi. Outra referência é a presença de três berimbaus acompanhados por atabaque, agogô, pandeiro e caxixi. Os berimbaus, como os três atabaques do candomblé, são considerados seres vivos, sagrados, e a eles se pede a bênção antes de começar o jogo (AMARAL; SILVA, 2006, p. 120).

As considerações dos autores citados acima oferecem elementos que nos ajudam a entender as redes de diálogo entre a capoeira e as religiões de matriz africana responsáveis pelas trocas simbólicas entre as duas manifestações. A existência dessas trocas simbólicas pode ser o elemento que faz com que algumas famílias, sobretudo as evangélicas, relacionem a capoeira ao candomblé. No entanto, como sinaliza CLIFFORD GEERTZ (1978), a cultura é uma rede de significados elaborados socialmente e seus sentidos são sempre provisórios e relativos. Nesse sentido, podemos dizer que os elementos do universo do candomblé podem assumir significados e sentidos diferentes e particulares no jogo da capoeira.

Apesar disso, a identificação de elementos comuns entre o candomblé e a capoeira faz com que a suposta questão religiosa seja utilizada como motivo para não permitir que as crianças participem da oficina de capoeira. Esse quadro evidencia a situação de intolerância religiosa no contexto escolar. Durante o tempo em que acompanhei as atividades de capoeira na Escola Berimbau, pude identificar sinais que apontavam para a presença de conflitos suscitados por motivações religiosas. Em uma das aulas de capoeira, as crianças estavam cantando junto com a professora: 


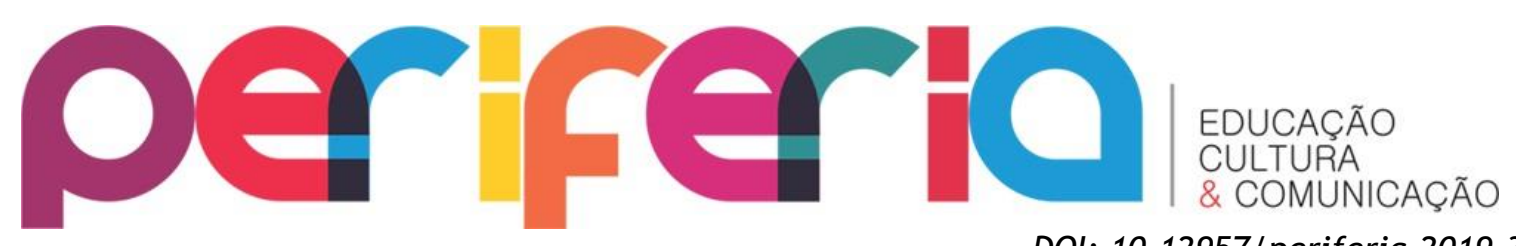

Ah, ah, ah eu não sei ler...

DOI: $10.12957 /$ periferia.2019.36382

Ah, ah, ah, quero aprender

Ah, ah, ah, a capoeira

Ah, ah, ah maculelê

No momento em que as crianças cantaram a palavra "maculelê", percebi alguns risos não muito comuns. Imediatamente pensei na questão religiosa; as suspeitas foram confirmadas quando um aluno chamou o outro de "macumbeiro", termo pejorativo usado para se referir às religiões de matriz africana como, por exemplo, candomblé e umbanda. Ao ouvir a conversa, a oficineira pediu que o aluno não falasse dessa forma com o colega. Ainda assim, o menino repetiu o termo duas vezes. Nesse momento, a Sol endureceu a crítica pedindo novamente para que ele não falasse daquela forma. No silêncio posterior à situação, ficou nítido que tanto quem buscou ofender como quem se sentiu ofendido reforçou a ideia do termo “macumba” como pejorativo.

Esse caso demonstra a dificuldade em lidar com a temática da intolerância religiosa. Quando o preconceito se manifesta no espaço da escola e nas aulas de capoeira, o caminho escolhido, por vezes, é o silêncio, pois não há uma tentativa de descontruir com as crianças a imagem que elas têm das religiões de matriz africana. Em 2014, a Escola Berimbau registrou outro caso de intolerância religiosa envolvendo a capoeira. Em conversa com a professora do $4^{\circ}$ ano, que organizou com a turma uma apresentação de capoeira para o festival de comemoração ao Dia da Consciência Negra ${ }^{18}$, ela relatou uma situação que evidencia, mais uma vez, sinais de intolerância religiosa ${ }^{19}$. De acordo com a referida professora, após desenvolver um trabalho sobre

${ }^{18}$ Em 2005, o prefeito Lindbergh Farias, do Partido dos Trabalhadores, sancionou a Lei $\mathrm{n}^{\circ} 3706$ na cidade de Nova Iguaçu. De acordo com essa lei, fica estabelecido a Semana Municipal da Capoeira, a ser comemorada na primeira semana do mês de novembro. A Semana Municipal da Capoeira dá início às comemorações ao mês em que é celebrada o Dia da Consciência Negra (20 de novembro). 0 texto integral da lei encontra-se no seguinte endereço eletrônico: <https://leismunicipais.com.br/a/rj/n/nova-iguacu/lei-ordinaria/2005/371/3706/lei-ordinaria-n3706-2005-cria-a-semana-municipal-da-capoeira>.

${ }^{19}$ A capoeirista que ajudou a construir a apresentação com a turma do $4^{\circ}$ ano não é a mesma que oferece a oficina de capoeira na Escola Berimbau. De acordo com a professora, ela chegou até a capoeirista por meio da indicação de uma mãe. Durante o tempo em que passei na escola, percebi uma dificuldade no diálogo entre as oficinas do PME e as demais atividades da escola. 


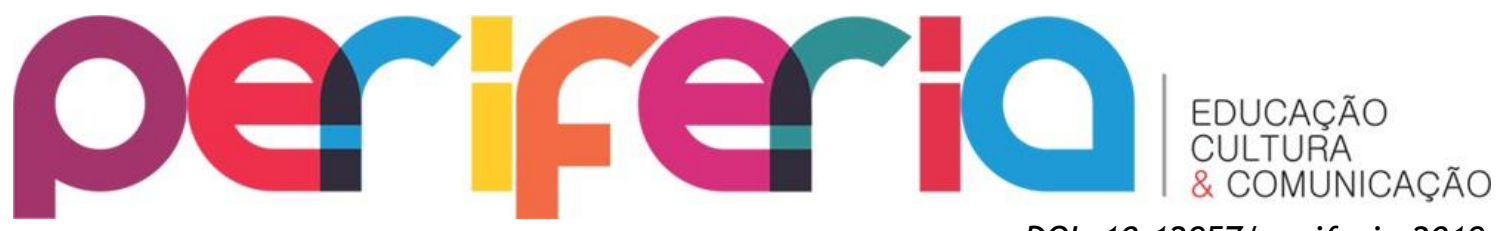

DOI: $10.12957 /$ periferia.2019.36382

a origem da capoeira com a turma do $4^{\circ}$ ano, ela programou uma apresentação de capoeira para a escola. No entanto, na data marcada para apresentação, apenas metade da turma esteve presente.

No dia posterior à apresentação, quando voltou a se reunir com toda a turma, a professora levantou o questionamento sobre o expressivo número de faltas. Nesse momento, de acordo com a docente, alguns alunos responderam dizendo que se ausentaram porque não queriam participar de uma apresentação de “macumba”. Diante da situação, a professora relatou que buscou apresentar a capoeira como uma expressão cultural; além disso, ela disse ainda que procurou reforçar com o grupo de estudantes a ideia de que a capoeira é uma prática esportiva e que, portanto, não tem nenhuma ligação com o universo religioso de matriz africana. Nesse sentido, a apresentação da capoeira como uma prática esportiva apresentou-se como uma alternativa para lidar com as manifestações de intolerância religiosa dos alunos. Tal abordagem também é adotada pela capoeirista responsável pela oficina de capoeira na Escola Berimbau. Ao ser questionada sobre como reage em relação à intolerância religiosa com foco na capoeira, ela respondeu:

[...] o preconceito ocorre diariamente, primeiro pela falta de informação, pois tudo que vem do negro é associado ao espiritismo. Assim como a capoeira, o samba também sofria preconceito religioso. Mas o que todo dia eu tento mudar é que a capoeira, como qualquer outra arte marcial, não tem religião. A religião é do indivíduo que a pratica.

O relato da Sol dialoga com o apontamento de Clifford Geertz sobre a cultura enquanto uma rede de significados. Quando pensamos no universo simbólico da cultura afro-brasileira, podemos identificar a presença recorrente de determinados elementos em diferentes manifestações que compõem tal universo. Nesse sentido, para determinados grupos, a presença de atabaques, de percussão e o uso de certas palavras que compõem algumas ladainhas são elementos suficientes para que eles liguem a capoeira às manifestações religiosas, reafirmando a suposta "inferioridade" do negro; "tudo que vem do negro é associado ao espiritismo", observa Sol, interpretando a perspectiva dos sujeitos que constituem os grupos mais intolerantes. 


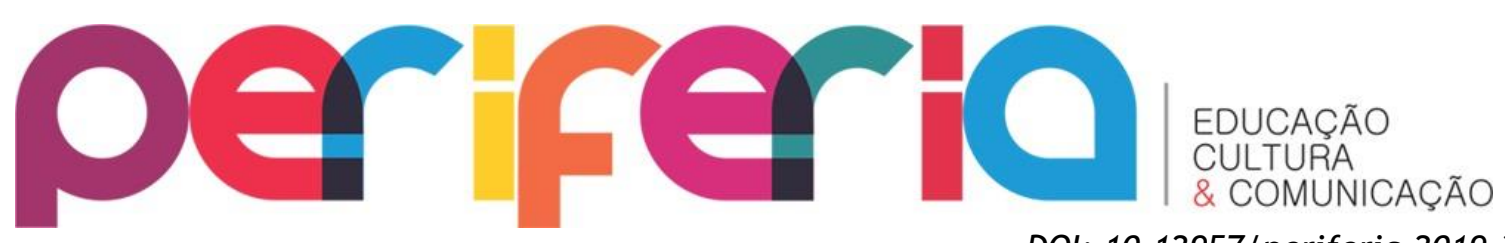

DOI: $10.12957 /$ periferia.2019.36382

$\mathrm{Na}$ tentativa de lidar com as tensões criadas por determinados grupos religiosos, a apresentação da capoeira como uma arte marcial ou como uma prática esportiva tem sido um caminho comum. Na Escola Berimbau, por exemplo, a professora que organizou uma apresentação de capoeira com sua turma, ao ser confrontada com a intolerância religiosa, buscou reforçar o caráter esportivo da capoeira. No caso da capoeirista responsável pela oficina no PME, ela sinaliza em seu relato a tentativa de desvincular a capoeira de qualquer interpretação religiosa, pois, como a própria docente ponderou, como qualquer outra arte marcial, a capoeira não tem religião.

Essa situação deixa em evidencia as contradições e conflitos que emergem a partir do diálogo entre a capoeira e a escola. Ao debruçarmo-nos sobre a história da capoeira identificamos movimentos que visam torná-la um esporte moderno (ELIAS; DUNNING, 1992). Tais movimentos podem ser interpretados como tentativas de dialogar com um contexto marcado pela resistência aos símbolos lidos como pertences ao universo das religiões de matriz africana. Contemporaneamente, a resposta dada por alguns grupos de capoeira à tensão criada pela intolerância religiosa assemelha-se, em certa medida, ao caminho seguido pelos grupos precursores desse movimento.

O entendimento da capoeira como uma arte marcial ou como uma prática esportiva demonstrou-se como um elemento estruturante nas aulas de capoeira na Escola Berimbau. Durante a observação, percebi que eram recorrentes a utilização de frases como: "você precisa ter uma postura de atleta", "atleta não deita no tatame”, entre outras. A organização das aulas também estava estruturada de modo a apresentar a capoeira como uma prática esportiva. Com exceção das aulas em que a musicalidade da capoeira era explorada, os encontros entre a oficineira de capoeira e os alunos da Escola Berimbau eram marcados por pedidos de exercícios de aquecimento como flexão, entre outros. Apesar de a oficineira reconhecer a capoeira como um elemento da cultura afro-brasileira e citar a Lei n 10639/03 como uma motivação para sua introdução na escola, ao citar os benefícios do diálogo entre a capoeira e a instituição escolar, ela elenca: “Os benefícios que a capoeira traz 


\section{periferio}

DOI: $10.12957 /$ periferia.2019.36382

para a vida escolar são muito grandes e ricos, pois se trabalha regras, limites, respeito, convivência em grupo, coordenação motora, disciplinar, entre outros”.

Verifica-se na narrativa da capoeirista uma série de benefícios que a capoeira proporciona aos alunos. Tais benefícios estão diretamente ligados aos discursos que defendem a introdução de práticas esportivas na escola. Em matérias sobre o diálogo entre a escola e o esporte presentes no site do $\mathrm{MEC}^{20}$, por exemplo, são elencados alguns benefícios citados pela oficineira de capoeira da Escola Berimbau: prevenção de problemas sociais, estímulo à cooperação e à socialização, coordenação motora, disciplina etc. Nesse sentido, por mais que haja um reconhecimento da capoeira como um elemento da cultura afro-brasileira, a visibilidade e o direcionamento do trabalho se deu a partir do seu entendimento como uma prática esportiva.

O caráter esportivo, além de estar presente no conteúdo das aulas, é reforçado por uma proposta do grupo de capoeira ao qual a oficineira está ligada. 0 grupo organiza, anualmente, uma atividade intitulada Copinha Capoeira Brincante. Abaixo podemos ver o cartaz de divulgação do evento, que, ao representar os capoeiristas, traz elementos do universo da capoeira regional e contemporânea ${ }^{21}$ como, por exemplo, a utilização de uniformes brancos e o sistema de cordas.

\footnotetext{
20 As matérias estão disponíveis em: <http://portal.mec.gov.br/component/tags/tag/33410>. Acesso em: 10 abr. 2015.

$21 \quad$ A capoeira regional é uma vertente da capoeira que tende, de um modo geral, a valorizar os aspectos esportivos da manifestação.
} 


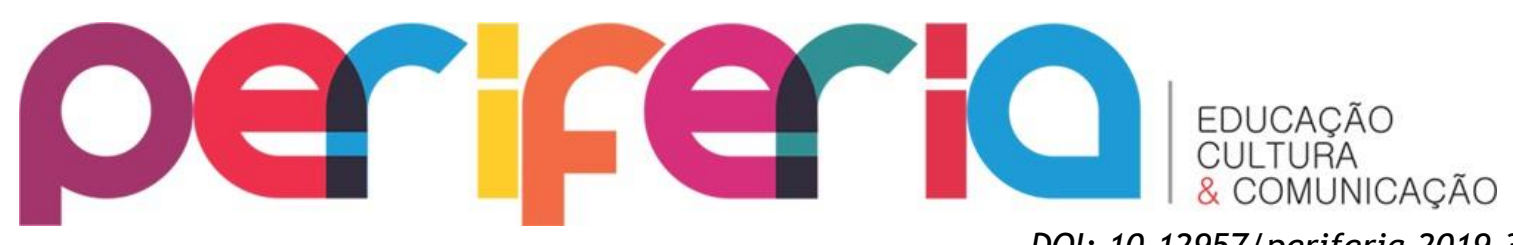

DOI: $10.12957 /$ periferia.2019.36382

Figura 2: Cartaz de divulgação da Copinha Capoeira Brincante, do Grupo Capoeira Brasil

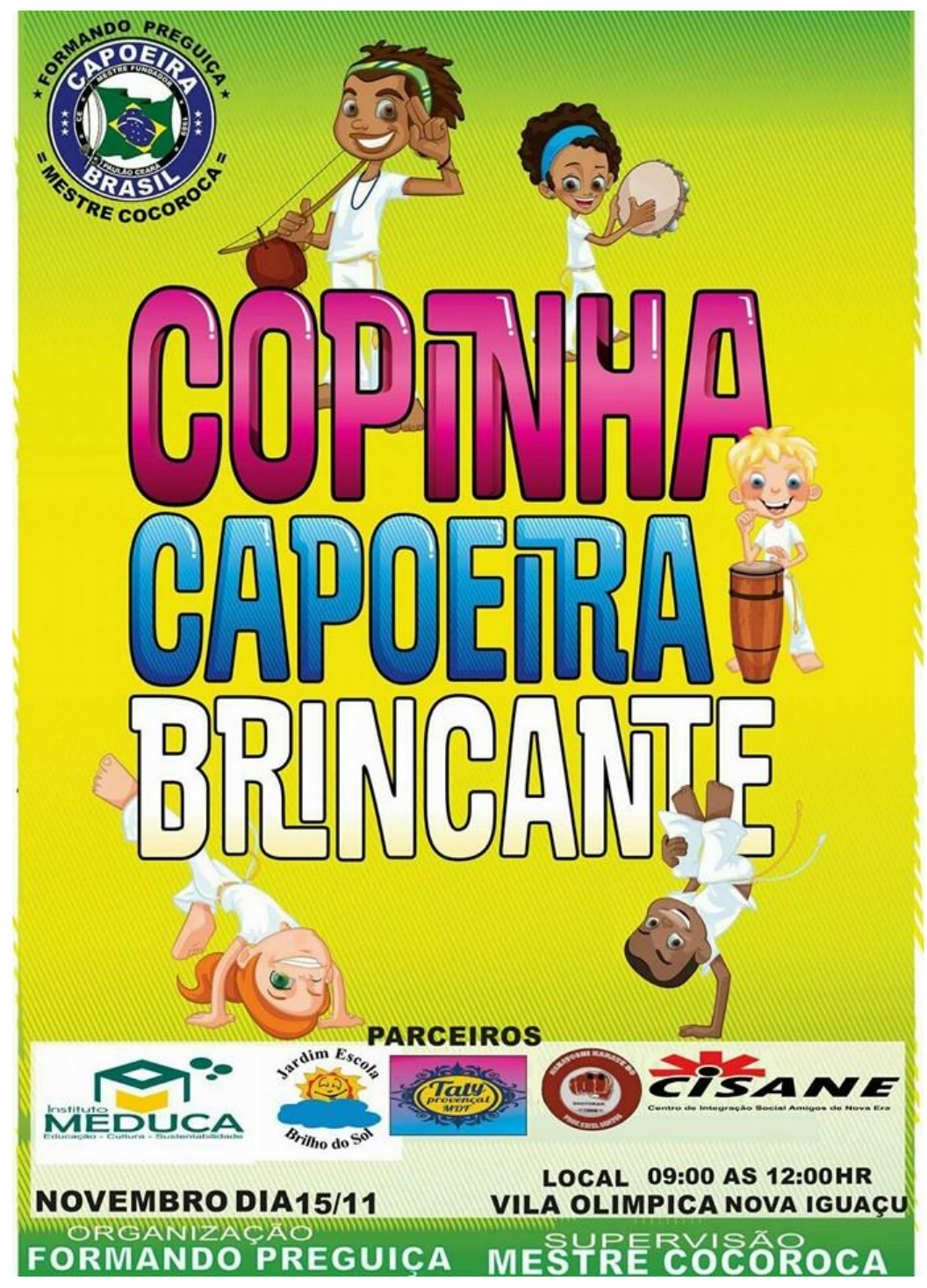

Fonte: Grupo Capoeira Brasil, 2014.

A Copinha Capoeira Brincante é um evento de competição que reúne estudantes de diferentes escolas onde o grupo desenvolve seus projetos. De acordo com a oficineira, no torneio são avaliados os movimentos e a ginga das crianças. Os estudantes da Escola Berimbau não participaram do evento, pois as aulas de capoeira só começaram no segundo semestre de 2014 e, segundo a oficineira, não foi possível passar todo o conteúdo planejado até a realização do evento. No entanto, ela sempre falava da competição, pois acreditava que essa era uma forma de estimular e chamar 


\section{periferio}

DOI: $10.12957 /$ periferia.2019.36382

a atenção das crianças. De fato, quando a oficineira falava da Copinha Capoeira Brincante, ela conseguia atrair o interesse das crianças, que ficavam curiosas e faziam perguntas sobre a premiação do evento.

Atrair a atenção de algumas crianças parecia, em algumas aulas, uma tarefa extremamente difícil, sobretudo quando se tratava dos meninos. As atividades com a capoeira aconteciam no mesmo espaço das aulas de educação física e da oficina de prática esportiva, que geralmente trabalhavam com o futebol. Diante dessa situação, as aulas de futebol se configuravam como uma competidora invencível e pedidos para troca de oficina eram comuns entre alguns meninos. As meninas, pelo contrário, mostravam-se interessadas nas aulas de capoeira e se esforçavam para gingar e para fazer os movimentos ensinados pela oficineira.

No entanto, apesar do interesse das meninas em participar das atividades propostas, em um dos acompanhamentos que fiz um fato me chamou a atenção. Nesse dia, a oficina estava dividindo o espaço com a oficina de práticas esportivas. Após a solicitação de troca de oficinas feita por alguns meninos, a turma da oficina de capoeira ficou com 12 crianças: 10 meninas e 2 meninos. A primeira atividade proposta foi uma corrida de aú (estrela), movimento utilizado pelo capoeirista para se locomover na roda. A turma foi dividida em dois grupos. Apesar de ter apenas um menino em cada grupo, eles foram escolhidos pela oficineira para liderar seus respectivos grupos, o que gerou a reclamação e a revolta das meninas que participavam da atividade.

A situação descrita no parágrafo anterior faz-me lembrar as ponderações de PIERRE BOURDIEU (1983) sobre a caracterização do esporte enquanto um campo marcado pela ação de sujeitos que disputam poderes simbólicos e materiais. 0 debate sobre as disputas, conflitos e contradições no campo do esporte tem sido levantado por outras pesquisas; José Jairo Vieira, por exemplo, ao analisar o rendimento salarial dos jogadores de futebol a partir do recorte racial, pondera:

[...] ao analisarmos os últimos estratos, percebemos que, na faixa salarial de 10 a 20 salários mínimos, encontramos 8,3 dos jogadores brancos contra $6,2 \%$ dos jogadores negros e $6,1 \%$ dos jogadores pardos. Esta diferença aumenta, ao observarmos o último estrato que compreende os rendimentos acima de 20 salários mínimos, neste 


\section{per
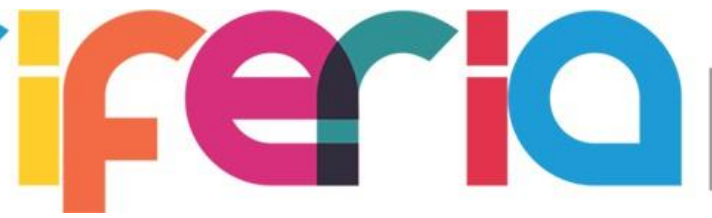 \\ EDUCAÇÃO \\ CULTURA \\ \& COMUNICAÇÃO}

DOI: $10.12957 /$ periferia.2019.36382

temos $24,8 \%$ dos jogadores brancos contra $14,8 \%$ dos negros e $12,2 \%$ dos pardos. (VIEIRA, 2003, p. 231).

O autor conclui seu artigo da seguinte forma:

Pode-se concluir que, apesar do reconhecimento da importância do futebol para a valorização e aceite do negro e pardo na sociedade brasileira, nesta atividade não ocorre uma neutralidade ou uma inexistência de discriminação. Os relatos e depoimentos dos jogadores revelam que existe nele, da mesma forma, que no restante da sociedade brasileira, práticas e atitudes discriminatórias contra negros e pardos (VIEIRA, 2003, p. 242).

A tentativa de diálogo com os trabalhos de Pierre Bourdieu e José Jairo Vieira visa sinalizar os conflitos presentes no campo do esporte. JOSÉ JAIRO VIEIRA (2003) evidencia a reprodução no futebol da desigualdade racial presente na sociedade brasileira. Nessa perspectiva, penso que o fato ocorrido durante a aula de capoeira demarca a hegemonia do gênero masculino na capoeira. Apesar de as meninas demonstrarem mais interesse na oficina, no momento de assumir um papel de destaque na atividade proposta, o espaço foi destinado aos meninos. Essa situação pode ser interpretada como uma reprodução da desigualdade de gênero vista na sociedade brasileira de um modo geral, e na capoeira de modo particular ${ }^{22}$.

Esse fato e os demais descritos neste artigo apontam para as diversas questões e problemáticas suscitadas pela introdução da capoeira no espaço escolar. Ao escolher a etnografia como uma das abordagens metodológicas desta pesquisa, visei, como bem sinalizou Clifford Geertz (1978, p. 20), “ler (no sentido de 'construir uma leitura de’)" as implicações do diálogo contemporâneo entre a escola e a capoeira. Não tenho a pretensão, com este trabalho, de dar conta de toda a discussão que gira em torno da relação entre a escola e a capoeira. A realidade social é dinâmica e, felizmente, esse debate tem sido atualizado cotidianamente.

\footnotetext{
22 Em entrevista com a capoeirista Sol, ela relatou as dificuldades vividas por uma mulher que trabalha com a capoeira: "[...] eu sou professora de uma arte marcial. A princípio eu encontrei dificuldades para treinar com bons mestres, porque eles não costumam abrir espaços para as mulheres. Depois eu encontrei dificuldade para dar aulas de capoeira, porque como eu sendo mulher poderia dar aula de capoeira? Então, assim, as dificuldades que eu encontro enquanto mulher são muitas, desde assédios, né? Até preconceito mesmo de que mulher não consegue ser professora de uma arte marcial".
} 


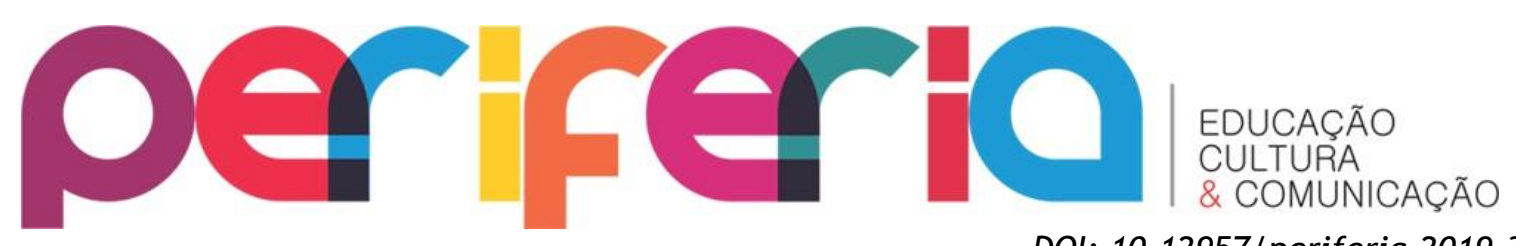

\section{REFERÊNCIAS}

DOI: $10.12957 /$ periferia.2019.36382

ALGEBAILE, E. B. Escola Pública e pobreza no Brasil: ampliação para menos. Rio de Janeiro: Lamparina/FAPERJ, 2009.

AMARAL, R; SILVA, V. G.. Religiões Afro-brasileiras e cultura nacional: uma etnografia em hipermídia. Caderno Pós Ciências Sociais (UFMA), São Luís, v. 3, nº 6, jul./dez. 2006, p. 107-130.

BOURDIEU, P. Como se pode ser desportista. In: BOURDIEU, P. Questões de sociologia. Rio de Janeiro: Marco Zero, 1983, p. 181-204.

BRASIL. Ministério da Educação. Manual Operacional de Educação Integral. Brasília, Distrito Federal, 2014. 71 p.

GEERTZ, C. A interpretação das culturas. Rio de Janeiro: Livros Técnicos e Científicos, 1978.

ELIAS, N. ; DUNNING, E. A Busca da Excitação. Lisboa: Difel, 1992.

MAINARDES, J. A abordagem do ciclo de políticas: uma contribuição para a análise de políticas educacionais. Educação \& Sociedade, Campinas, v. 27, n. 94, jan./abr. 2006. p. 47-69.

SILVA, J. A. de A. da; SILVA, K. N. P. As políticas sociais e a "nova estratégia" de educação integral no Brasil. Série-estudos: Período do Programa de Pós-graduação em Educação UCDB, Campo Grande, MS, n. 36, p. 109-128, jul./dez. 2013.

TURA, Maria de Lourdes Rangel. A observação do cotidiano escolar. In: ZAGO; CARVALHO; VIVELA (Org.). Itinerários de pesquisa / Perspectivas qualitativas em Sociologia da Educação. Rio de Janeiro: DP\&A, 2011, p. 183-206.

VIEIRA, J. J. Preconceito e Discriminação Racial no Futebol Brasileiro. Teoria \& Pesquisa, São Carlos, v. 42-43, p. 221-244, 2003.

WEBER, Demétrio. Infraestrutura precária é o problema mais citado por secretários de educação. 0 Globo, $1^{\circ}$ fev. 2013. Disponível em: <http://oglobo.globo.com/sociedade/educacao/infraestrutura-precaria-o-

problema-mais-citado-por-secretarios-de-educacao-7472648>. Acesso em 10 jul. 2015.

ZUAZO, Pedro. Baixada Fluminense no Ideb: municípios mantêm escolas precárias e notas ficam abaixo da meta. Jornal Extra, Rio de Janeiro, 14 set. 2014. Disponível em: <http://extra.globo.com/noticias/rio/baixada-fluminense-no-ideb-municipiosmantem-escolas-precarias-notas-ficam-abaixo-da-meta-13930021.html>. Acesso em 10 jul. 2015. 